\title{
Self-Compassion in Clinical Samples: A Systematic Literature Review
}

\author{
Dimitra Athanasakou, Eirini Karakasidou, Christos Pezirkianidis, Agathi Lakioti, Anastassios Stalikas
}

Panteion University of Social and Political Sciences, Athens, Greece

Email: irenekarakasidou@yahoo.com

How to cite this paper: Athanasakou, D., Karakasidou, E., Pezirkianidis, C., Lakioti, A., \& Stalikas, A. (2020). Self-Compassion in Clinical Samples: A Systematic Literature Review. Psychology, 11, 217-244. https://doi.org/10.4236/psych.2020.112015

Received: August 2, 2019

Accepted: February 7, 2020

Published: February 10, 2020

Copyright $\odot 2020$ by author(s) and Scientific Research Publishing Inc. This work is licensed under the Creative Commons Attribution International License (CC BY 4.0).

http://creativecommons.org/licenses/by/4.0/

\begin{abstract}
Self-compassion, broadly, means to treat oneself kindly in times of need, same as one would do with a dear friend (Neff, 2003b). This systematic review focuses on self-compassion as is found in clinical samples. It specifically reviews 28 relevant studies to find out if people belonging in what is called "clinical samples" have lower levels of self-compassion than those of non-clinical samples in the first place and if this is a crucial factor for the appearance of psychopathological symptoms (i.e. anxiety disorders, bipolar disorder, borderline personality disorder, PTSD, depression, schizophrenia etc.), or it is the other way around. Even though most studies tend to agree that low self-compassion and psychopathology are present in clinical samples, no study until now can prove a clause for causality, as most studies were of a cross-sectional design and had a great heterogeneity concerning both mental health issues involved and ages/genders. Future studies could use additional mediators to check out how low self-compassion and mental health are connected. Another question to be asked is if self-compassion is equally important for one's recovery as it is for the prevention of appearance of mental illness. The systematic review highlights issues from the current evidence that may be used for further research.
\end{abstract}

\section{Keywords}

Self-Compassion, Clinical, Psychopathology, Systematic Review

\section{Introduction}

Even though the East and the West have been two worlds apart for a lot of years, lately there's a shift and the Western world has been looking into what it might learn from its sister world, the East. In the West, psychiatry is still king. In the East, one can find purer solutions to one's problems: yoga, Buddhism and sever- 
al other peaceful concepts. One of those notions of the Buddhist philosophy is self-compassion. Self-compassion, a concept firstly researched and defined by Kristin Neff (2003b) actually means to be able to treat oneself as one would be a loved one, in times of need: with kindness, warmth, acceptance. Compassion and self-compassion are, of course, interrelated. "To have compassion means to be attentive to and be touched by one's pain", Neff (2003b) writes. To have self-compassion is to be able to do all of the above, when it comes to yourself. Neff (2003b) defines self-compassion as

"being touched by and open to one's own suffering, not avoiding or disconnecting from it, generating the desire to alleviate one's suffering and to heal oneself with kindness. Self-compassion also involves offering nonjudgmental understanding to one's pain, inadequacies and failures, so that one's experience is seen as part of the larger human experience" (p. 87).

According to Neff's (2003a) description, self-compassion consists of three elements:

"1) self-kindness-being kind and understanding toward oneself in instances of pain or failure rather than being harshly self-critical, 2) common humanity-perceiving one's experiences as part of the larger human experience rather than seeing them as separating and isolating, and 3) mindfulness-holding painful thoughts and feelings in balanced awareness rather than over-identifying with them" (p. 85).

These three components, while distinct in their conceptual level, are interconnected and to name a person as self-compassionate, it is crucial that they can exhibit all of them in a degree or another (Neff, 2009).

Research has shown again and again the importance self-compassion can have for a person's life and the list of evidence keeps growing. Self-compassion is connected with more happiness, greater life-satisfaction, better emotional regulation, a muted sense of self-criticism and a better interpretation of academic failure, to mention just a few of the advantages (Barnard \& Curry, 2011; Neff, Hsieh, \& Dejitterat, 2005). Self-compassion seems to be a great asset for one's more positive sense of well-being and it appears to make people feel safer and more in peace with their doings or misdoings (Zessin et al., 2015). Accumulating evidence shows that it acts like an armor, protecting oneself against psychopathological symptoms (Barnard \& Curry, 2011; MacBeth \& Gumley, 2012). Resilience to mental health issues appears to be interconnected with the ability to be self-compassionate (Trompetter et al., 2016). The bibliography shows that self-compassion is a great source of strength for a person's mental health and a lot of study findings show that it can be a protective factor against depression and anxiety as rumination and stress tend to be moderated when self-compassion appears (Barnard \& Curry 2011; Ehret et al. 2014; MacBeth \& Gumley 2012; Samaie \& Farahani, 2011). Because self-compassionate people are kind, mindful with their own pain and do not over-identify with it, but treat 
themselves with support and care, they appear to have a better cognitive reappraisal and acceptance when situations are hard (Allen \& Leary 2010; Leary et al., 2007). Research findings depict that people with self-compassion don't develop depressive symptoms as much but there isn't sufficient literature on how self-compassion acts as a resilience mechanism in relation to psychopathology (Diedrich et al. 2014; Trompetter et al., 2016).

Reading said literature, the question arises, how is self-compassion connected with the field of mental health when the population is that of a clinical sample? To define mental health can be a tricky issue as psychiatry tends to divide people into mentally healthy or unhealthy (Keyes, 2005). Even though this division doesn't seem to do justice to either being healthy or unhealthy when it comes to mental states, this paper will adopt the description of modern psychiatry and clinical psychology to have a common ground with the studies being reviewed. What does the literature say about the relationship between self-compassion and what psychiatric tools like the DSM-V (American Psychiatric Association, 2013) and the ICD-10 (World Health Organization, 1992) regard as psychopathology (i.e., major depressive episode, generalized anxiety, borderline personality disorder, bipolar disorder, alcohol dependence etc.)? This systematic review will try to bring forward the body of research dedicated to how exactly self-compassion relates to clinical samples.

At first, MacBeth and Gumley's (2012) meta-analysis explored compassion and more specifically self-compassion and its associations to psychopathology, but they mostly focused in what they refer to as "common" psychopathology that is anxiety, depression and stress. They also cared to evaluate how demographic moderator variables like sampling and gender affected the relationship between compassion and psychopathology.

Later, Muris \& Petrocchi (2016) attempted a systematic literature search and meta-analysis, too, including a much broader spectrum of psychopathological symptoms. Their main concern was to see if self-compassion could act protectively to psychopathology and also, to explore the relations between the positive and negative aspects of self-compassion and psychopathology, but they only included studies that specifically had to do both with the "positive" and "negative" subscales of these measures, apart from the total scores.

This systematic literature review differs in that it will focus on the research papers published only the last six years (i.e. from 2012 and later) and will explore the relationship between self-compassion and psychopathology in clinical samples. The focal point of this review is to explore if people of clinical samples have lower levels of self-compassion than those of non-clinical samples in the first place and if this is a crucial factor for the appearance of psychopathological symptoms (i.e. anxiety disorders, bipolar disorder, borderline personality disorder, PTSD, depression, schizophrenia etc.) or the other way around. The paper has excluded from its review eating disorders as a systematic review recently published (Braun et al., 2016) sufficiently covered the pertinent topic. 
This systematic review focuses on self-compassion as is found in clinical samples. It specifically reviews 28 relevant studies to find out if people belonging in what is called "clinical samples" have lower levels of self-compassion than those of non-clinical samples in the first place and if this is a crucial factor for the appearance of psychopathological symptoms (i.e. anxiety disorders, bipolar disorder, borderline personality disorder, PTSD, depression, schizophrenia etc.), or is it the other way around.

\section{Method}

Relevant data were collected using Kristin Neff's website, the Pubmed database and google scholar. At first, Kristin Neff s homepage was visited and there's a category there, named "research" (http://self-compassion.org/the-research/), which gives away a collected database of almost everything ever written on the subject of self-compassion. She has categorized the work both according to areas of study and alphabetically. In the area of study "Self-compassion in Clinical Contexts" she has collected 74 relevant publications. After this, pubmed database was used with the search keywords "self-compassion AND clinical samples", "self-compassion AND psychopathology", "self compassion AND psychopathology", "self-compassion AND DSM", "self compassion AND DSM" and the same keywords were used in Google scholar to see if anything different came up.

The search gave a number of studies, but to include them in the review they had to be written in the English language and to be published from 2012 and later. Papers which didn't mention research data, literature articles only based on bibliography or opinion and meta-analyses were excluded. There was a compare and contrast with Neff's list of publications and after reading the titles and the abstracts, 28 papers were selected for this systematic literature review. Selected studies had to do with self-compassion in the field of clinical samples and psychopathology as defined by the ICD-10, DSM-IV and the DSM-V. For the measurement of this concept, most researchers have relied on the Self-Compassion Scale of 26 questions (SCS; Neff, 2003a) or its abbreviated version, the Self-Compassion Scale-Short Form, with 12 questions (SCSSF; Raes, Pommier, Neff, \& Van Gucht, 2011).

\section{Results}

Overall, 28 studies were included in this systematic review and they're organized alphabetically in the table above (Table 1, Results.) Most of the studies used quantitative methods to analyze their data.

\subsection{Self-Compassion and Anxiety Disorders}

In a study with people with Generalized Anxiety Disorder (GAD) it was shown that GAD patients reported lower mindfulness and self-compassion levels and higher levels of worry and anxiety (Hoge et al., 2013). According to another 
Table 1. Results.

\begin{tabular}{|c|c|c|c|c|}
\hline Reference & Study Design & Study Aim & Measure & Sample \\
\hline $\begin{array}{l}\text { Beaumont et al. } \\
\text { (2012) }\end{array}$ & $\begin{array}{l}\text { Prospective, } \\
\text { comparative } \\
\text { outcome study } \\
\text { (repeated } \\
\text { measures } \\
\text { design) }\end{array}$ & $\begin{array}{l}\text { To contrast the } \\
\text { relative impact of differing } \\
\text { therapeutic interventions } \\
\text { for trauma victims, carried } \\
\text { out by the same therapist. }\end{array}$ & $\begin{array}{l}12 \text { sessions of either } \\
\text { Cognitive } \\
\text { Behavior Therapy (CBT), } \\
\text { lor CBT coupled with } \\
\text { Compassionate Mind } \\
\text { Training (CMT). Data was } \\
\text { gathered pre-therapy } \\
\text { and post-therapy, using } \\
\text { three self-report } \\
\text { questionnaires: Hospital } \\
\text { Anxiety and Depression } \\
\text { Scale; Impact of } \\
\text { Events Scale; the } \\
\text { Self-Compassion Scale } \\
\text { (SCS). }\end{array}$ & $\begin{array}{l}\text { A non-random } \\
\text { convenience sample } \\
(\mathrm{N}=32) \text { of participants, } \\
\text { referred for therapy } \\
\text { following a traumatic } \\
\text { incident. }\end{array}$ \\
\hline
\end{tabular}

Braehler et al. (2013)
Brooks et al. (2012)
Prospective, randomized, open-label, blinded end point associated change evaluation clinical processes of using group trial. benefits, and Compassion focused
To assess the safety, the Compassion focused acceptability, the potential therapy change processe recovering from psychosis. Impression-Improvement

\section{Scale (CGI-I), the}

Narrative

Recovery Style Scale

(NRSS), The Beck

Depression Inventory-II, e

Fear of Recurrence Scale

(FORSE), Personal Beliefs

about Illness

Questionnaire-Revised

(PBIQ-R)

Treatment as usual (TAU), and Group compassion focused therapy (CFT): patients with a schizophrenia-spectrum disorder were randomized to CFT plus treatment as usual (TAU; $\mathrm{n}=22$ ) or to TAU alone $(\mathrm{n}=18)$.

Group CFT comprised 16 sessions ( $2 \mathrm{hr}$ each, $1 \mathrm{x}$ week)

The baseline questionnaire Participants At baseline, study consisted of a range of $\quad(\mathrm{N}=77,42$ male and 35 participants were demographic information female), aged from 19 to significantly higher in including gender, 69 years, with depression, anxiety, stress, education, income, a primary presentation of alcohol date of birth and alcohol dependence based use, and lower in 


\begin{tabular}{|c|c|c|c|c|c|}
\hline & study) & $\begin{array}{l}\text { alcohol use at entry to } \\
\text { treatment. }\end{array}$ & $\begin{array}{l}\text { involvement in drug and } \\
\text { alcohol } \\
\text { Mindfulness } \\
\text { rehabilitation services. } \\
\text { Also, the Depression, } \\
\text { Anxiety } \\
\text { and Stress Scale } \\
\text { (DASS-21), } \\
\text { the Opiate Treatment } \\
\text { Index (OTI1) and the } \\
\text { Self-compassion scale and } \\
\text { the alcohol scale of the } \\
\text { OTI. }\end{array}$ & $\begin{array}{l}\text { on a } \\
\text { DSM-IV diagnosis. } \\
\text { Participants were both } \\
\text { new and existing clients } \\
\text { of the Central Coast Drug } \\
\text { and Alcohol Counselling } \\
\text { Service in Australia. }\end{array}$ & $\begin{array}{l}\text { self-compassion than the } \\
\text { general population. } \\
\text { At } 15 \text { weeks follow-up, } \\
\text { participants reported a } \\
\text { significant } \\
\text { increase in } \\
\text { self-compassion, } \\
\text { mindfulness, common } \\
\text { humanity } \\
\text { and self-kindness and } \\
\text { significant decreases in } \\
\text { self-judgement, } \\
\text { isolation and } \\
\text { over-identification. }\end{array}$ \\
\hline $\begin{array}{l}\text { Collett et al. } \\
(2016)\end{array}$ & Cross-sectional & $\begin{array}{l}\text { Five concepts in patients } \\
\text { with persecutory } \\
\text { delusions: } \\
\text { 1) self-compassion, } \\
\text { 2) schema, } \\
\text { 3) self-stigma, } \\
\text { 4) fears of madness } \\
\text { and } \\
\text { 5) self-esteem in } \\
\text { association with suicidal } \\
\text { ideation. }\end{array}$ & $\begin{array}{l}\text { Psychotic Symptom Rating } \\
\text { Scale - Delusions } \\
\text { (PSYRATS), } \\
\text { The Positive and Negative } \\
\text { Syndrome Scales (PANSS), } \\
\text { Persecution and } \\
\text { Deservedness Scale } \\
\text { (PaDS), The } \\
\text { Self-Compassion Scale } \\
\text { (SCS), The Brief Core } \\
\text { Schema Scale (BCSS), } \\
\text { Self-Stigma of Mental } \\
\text { Illness Scale (SSMIS), } \\
\text { Mental Health Worries } \\
\text { Questionnaire (MHWC), } \\
\text { Rosenberg Self-esteem } \\
\text { Scale (RSES), } \\
\text { Social Comparison Scale } \\
\text { (SCS), Beck Depression } \\
\text { Inventory (BDI), Beck } \\
\text { Scale for Suicidal Ideation } \\
\text { (BSS) }\end{array}$ & $\begin{array}{l}\text { gParticipants over } 18 \text { years } \\
\text { old, English being their } \\
\text { mother language, with an } \\
\text { experience of a current } \\
\text {,persecutory } \\
\text { delusion as defined by } \\
\text { Freeman and Garety } \\
(2000) \text {; a clinical diagnosis } \\
\text { of non-affective psychosis } \\
(\mathrm{n}=21) \\
\text { and the Control group, } \\
\text { same but without any } \\
\text { reported mental health } \\
\text { problem ( } \mathrm{n}=21) \\
\text { in England }\end{array}$ & $\begin{array}{l}\text { The } \\
\text { persecutory delusion } \\
\text { group had many more } \\
\text { negative self-cognitions } \\
\text { and fewer positive } \\
\text { self-cognitions. } \\
\text { Suicidal ideation was } \\
\text { highly associated } \\
\text { with low self-compassion, } \\
\text { low self-esteem, negative } \\
\text { self-schema, } \\
\text { and negative } \\
\text { self-comparisons to others. } \\
\text { Fears of madness } \\
\text { and depression were also } \\
\text { significantly related to } \\
\text { suicidal ideation. } \\
\text { Patients } \\
\text { with persecutory delusions } \\
\text { experience severe feelings } \\
\text { of } \\
\text { being inferior to others, } \\
\text { worry that they are mad, } \\
\text { and have lower } \\
\text { self-compassion. }\end{array}$ \\
\hline $\begin{array}{l}\text { Diedrich et al. } \\
\text { (2014) }\end{array}$ & $\begin{array}{l}\text { Experimental } \\
\text { design }\end{array}$ & $\begin{array}{l}\text { To compare the } \\
\text { effectiveness of } \\
\text { self-compassion with } \\
\text { a waiting condition, } \\
\text { reappraisal, and } \\
\text { acceptance in a clinically } \\
\text { depressed sample, and to } \\
\text { test the hypothesis } \\
\text { that the intensity of } \\
\text { depressed mood would } \\
\text { moderate the differential } \\
\text { efficacy of these strategies. }\end{array}$ & $\begin{array}{l}\text { The Structured Clinical } \\
\text { Interview for } \\
\text { DSMeIV Axis I and II } \\
\text { Disorders (SCID; German } \\
\text { version). Experimental } \\
\text { session. After the } \\
\text { experiment, subjects } \\
\text { completed a short } \\
\text { post-survey. }\end{array}$ & $\begin{array}{l}\mathrm{N}=48 \text { clinically depressed } \\
\text { participants. } \\
\text { Inclusion criteria were a } \\
\text { current clinical diagnosis } \\
\text { of MDD, } \\
\text { age } 18 \text { and above, and } \\
\text { proficiency in the German } \\
\text { language. The } \\
\text { majority of participants } \\
\text { were female ( } 62.5 \%) \text {. The } \\
\text { average age of the } \\
\text { participants was } 35.7 \\
\text { years. }\end{array}$ & $\begin{array}{l}\text { The reduction of } \\
\text { depressed mood was } \\
\text { significantly } \\
\text { greater in the } \\
\text { self-compassion condition } \\
\text { than in the waiting } \\
\text { condition. No significant } \\
\text { differences were } \\
\text { observed between the } \\
\text { self-compassion and the } \\
\text { reappraisal condition, and } \\
\text { between the } \\
\text { self-compassion } \\
\text { and the acceptance } \\
\text { condition in patients' } \\
\text { mood ratings. }\end{array}$ \\
\hline $\begin{array}{l}\text { Diedrich } \\
\text { et al. (2016) }\end{array}$ & $\begin{array}{l}\text { Randomized } \\
\text { control trial }\end{array}$ & $\begin{array}{l}\text { To examine } \\
\text { whether the efficacy of } \\
\text { explicit cognitive } \\
\text { reappraisal in major }\end{array}$ & $\begin{array}{l}\text { The experiment consisted } \\
\text { of four negative } \\
\text { mood induction phases } \\
\text { and four respective ER }\end{array}$ & $\begin{array}{l}\mathrm{N}=54 \text { ( } 64.8 \% \text { female; age } \\
\mathrm{M}=35.59 \text { individuals who } \\
\text { met criteria for Major } \\
\text { Depressive Disorder }\end{array}$ & $\begin{array}{l}\text { Participants who had } \\
\text { utilized self-compassion as } \\
\text { a preparatory strategy } \\
\text { experienced }\end{array}$ \\
\hline
\end{tabular}


depressive disorder can be phases. Negative mood enhanced was through the use of self-compassion and emotion-focused induced with low-mood inducing music (extract from "Adagio in $\mathrm{G}$ acceptance as preparatory minor" by Tomaso strategies.

Cross-Sectional was played in the background and a modified Velten mood induction procedure. ER the speaker you will be taught a strategy to regulate your Self-compassion, Emotion-focused acceptance, Waiting condition. Assessment Diagnoses were derived using the Structured Clinical Interview for DSM-IV Axis I and II Disorders.
Eicher et al. (2013)
Exploratory, correlational study
To explore the relationship between self-compassion, symptoms and insight in individuals with schizophrenia.
Giovanni Albinoni) which strategies were introduced by the presentation of the following sentence on the computer screen: Through mood Explicit reappraisal,

Self-Compassion Scale Bipolar disorder patients Patients with bipolar self-compassion is linked (SCS), Altman Self-Rating (ICD-10) $(\mathrm{n}=30)$ (mean disorder had significantly to psychopathology and in Mania Scale (ASRM), particular in patients with Major Depression Bipolar Disorder (BD). Inventory (MDI), Work and Social Adjustment Scale (WSAS), (each group contained 9 Satisfaction With Life males and 21 females) Scale (SWLS), Internalized $(\mathrm{n}=30)$. All were Stigma of Mental Illness recruited from the Mood Scale (ISMI-10) and Disorders further reported their Clinic at Aarhus illness history on a survey University Hospital in sheet. Denmark.

Positive and Negative 76 men and 12 women Syndrome Scale (PANSS), with an SCID Scale to Assess confirmed diagnosis schizophrenia $(\mathrm{n}=51)$ or schizoaffective disorde (Abbreviated) (SUMD), Beck Cognitive $(\mathrm{n}=37)(\mathrm{N}=88)$. The Insight Scale (BCIS), The mean (SD) age of the Self-Compassion Scale (SCS), Marlowe-Crowne Social Desirability Scale (MCSDS) disorder had significan than controls.

Self-compassion correlated positively and significantly with life-satisfaction but no significant correlations with functional impairment, internalized stigma or frequency of past affective episodes

Higher self-compassion scores were associated with lower scores on the Positive and Negative Syndrome Scale positive, excitement and emotional discomfort symptom scales in addition to poorer insight. were found. participants was 49.61 years and there were recruited from a Midwestern Veterans Affairs (VA) medical center or community mental health center. significantly greater reduction of depressed mood during reappraisal than did those who had been instructed to wait prior to reappraisal. Participants who had used acceptance as a preparatory strategy did not experience a significantly greater reduction of depressed mood during subsequent reappraisal than those in the waiting condition. Patients were allocated to Thirty-two patien
LKM/CM or mindfulness diagnosis of BPD loving-kindness and 


$\begin{array}{ll}\text { Gilbert et al. } & \begin{array}{l}\text { Exploratory, } \\ \text { correlational }\end{array} \\ & \text { study }\end{array}$

Gumley \& Macbeth (2014)

Pilot study

(intervention)

rogramme in

loving-kindness and

compassion meditation

(LKM/CM) in patients

with borderline

personality disorder

(BPD). continuation training

(control group).

Interventions:

Both interventions were group-based. The 3-week LKM/CM intervention included

psychoeducational content from Gilbert's theoretical model of compassion and Neff \& Germer vision Diagnostic Interview for Borderlines Revised, Borderline Symptom

List-23 (BSL-23),

Self-Compassion Scale

(SCS), Forms of

Self-Criticism/Self-Attacki

ng and Self Reassuring

Scale (FSCRS),

Philadelphia Mindfulness

Scale (PHLMS)

Explores the relationship Fears of Compassion

between fears of Scales, The Toronto

compassion and happiness Alexithymia Scale

Students from the University of Derby participated in the study in general, with capacities (TAS-20), The Five Facets for emotional processing of Mindfulness (alexithymia), capacities Questionnaire (FFMQ), for mindfulness, and Davis Interpersonal empathic abilities. To Reactivity Index, Types of advance this research, a Positive Affect Scale, new scale was developed Forms of Self-Criticism to measure general fears of and Self-Reassurance positive feelings-the Fear Scale, The Depression, of Happiness Scale.

Anxiety, and Stress Scale (DASS-42), Fear of Happiness Scale. (experimental correlational)

DSM-IV-TR criteria.

\section{To explore}

associations between

Narrative Compassion

Interview (NCI),

compassion and clinical Narrative Compassion

symptoms in a group of Scale (NCS),

individuals with psychosis PANSS,

and the

Self-Compassion

further development of a Scale (SeCS)

narrative-based measure

of compassion. according to

compassion meditations

18 to 45 years, and experience in patients with

male

BPD. Significant

$(\mathrm{n}=2)$ and female

$(\mathrm{n}=30)$ Caucasians.

improvements in the severity of borderline symptoms, self-criticism, mindfulness, acceptance and self-kindness were observed after the LKM/CM intervention.
$(N=185)$. Participants

were 153 women and 32 linked to different aspects men with an age range of of alexithymia, 18 - 57 years $(M=27.97)$ mindfulness, empathy, self-criticism and depression, anxiety and stress.
( $N=29)$ Participants were Greater narrative under the care of NHS compassion was associated Greater Glasgow and Clyde (NHS GG\&C) mental health services and met with less negative symptoms, less cognitive disorganisation Diagnostic and Statistical correlations were found Manual between narrative of Mental Disorders-4th compassion and the Edition (DSM-IV) criteria Self-Compassion Scale. for an affective or non-affective psychotic disorder with a diagnosis of psychotic disorder. Average age was 40.6 years old, predominantly male $(\mathrm{n}=$ $25,86.2 \%)$, white Scottish $(\mathrm{n}=27,93.1 \%)$ and single $(\mathrm{n}=20,69.0 \%)$ 


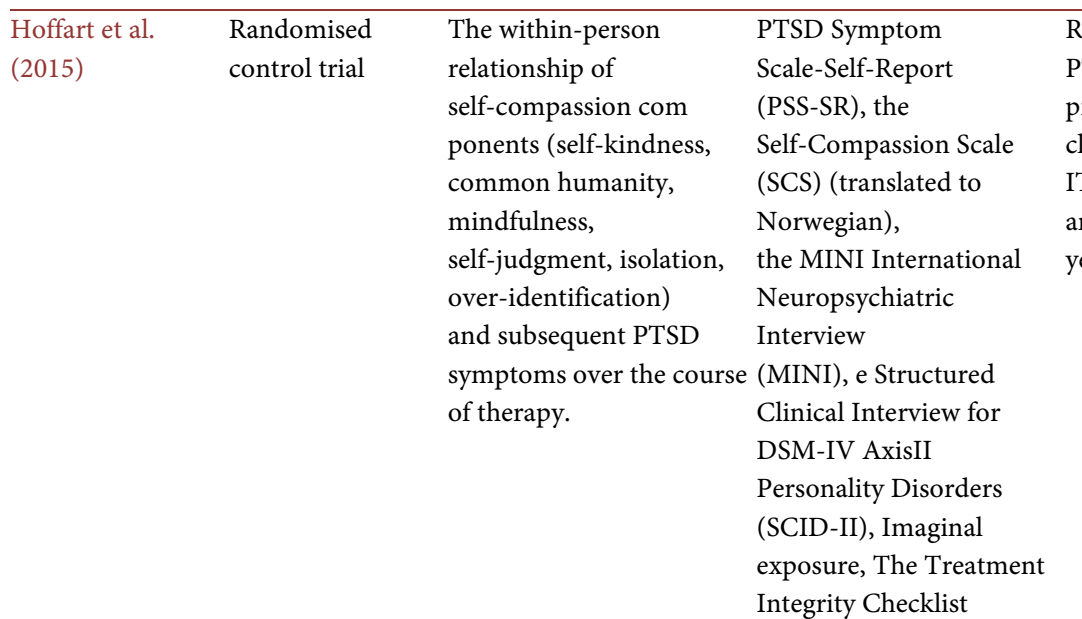

Hoge et al. (2013) Cross-Sectional

Joeng \& Turner Cross-Sectional (2015) approaches.

Measures for Healthy Controls Experiencing Stress Only: Perceived Stress Scale (PSS).

$\begin{array}{ll}\text { Construction of a } & \text { The Levels of } \\ \text { hypothesized model that } & \text { Self-Criticism Scale }\end{array}$
Referrals $(\mathrm{N}=65)$ to a The self-compassion

PTSD treatment components self-kindness, program at a National self-judgment, isolation, clinic. The mean age of 65 and over-identification ITT patients-38 women had a within-person effect and 27 men-was 45.2 on subsequent PTSD years. symptoms, independently of therapy form. The within-person relationship between self-judgment and subsequent PTSD symptoms was stronger in patients with higher initial self-judgment. Few indications that within-person variations in PTSD symptoms predict subsequent self-compassion components.

Whether GAD Five Facet Mindfulness Individuals with current GAD patients had lower (Generalised Anxiety Questionnaire (FFMQ), GAD as defined by the mindfulness and Disorder) patients would the Self-Compassion Scale DSM-IV-TR criteria and self-compassion than report lower mindfulness (SCS), The Structured healthy controls with high healthy stressed controls, and self-compassion levels Clinical Interview for ratings of subjective stress and both were negatively than healthy stressed DSM-IV (SCID), Anxiety were recruited to the correlated with levels of individuals, In order to Sensitivity Index (ASI), Massachusetts General anxiety, worry, and advance treatment Penn State Worry Hospital Department of anxiety sensitivity.

Questionnaire (PSWQ), Psychiatry to participate in Mindfulness was a better State Trait Anxiety a stress reduction course. predictor of disability than Inventory Trait (STAI). GAD patients $(n=87) \quad$ actual anxiety symptom Measures for GAD (51.22\% females; mean agescores.

Individuals Only: Sheehan 39.4 years) and 49 healthy Disability Scale (SDS) and controls $(\mathrm{n}=49)(65.31 \%$ Beck Anxiety Scale (BAI). females; mean age 38.7) models (LOSC),

relationships between The Self-Rating self-criticism, depression Depression Scale (SDS), and the proposed mediators (relationships between self-criticism and Self-Compassion Scale (SCS) depression, and the Importance Scale of the Mattering Index, mediating roles of fear of compassion, The Fear of Compassion self-compassion, and the perception that one is important to others as a dimension of mattering.)
$\mathrm{N}=260$ university In the students at a large public Self-Criticism/Compassio Midwestern n Mediation Model, the university in the United fear of self-compassion, States recruited through and the perception that student e-mail lists, one is psychology classes, important to others and flyers on campus.38 serially mediated the (18.4\%) were relationship between men and 168 (81.6\%) were comparative self-criticism women, with ages ranging and depression. 52 years (Mean age: 21.42 self-compassion partially years) mediated both the relationship between internalized self-criticism and depression, and the relationship between comparative self-criticism and depression. from 17 to Additionally, 


\begin{tabular}{|c|c|c|c|c|c|}
\hline $\begin{array}{l}\text { Krieger et al. } \\
(2016)\end{array}$ & $\begin{array}{l}\text { Longitudinal } \\
\text { Study }\end{array}$ & $\begin{array}{l}\text { Whether (lack of) } \\
\text { self-compassion is a cause } \\
\text { or } \\
\text { a consequence of } \\
\text { depressive symptoms, or } \\
\text { both. }\end{array}$ & $\begin{array}{l}\text { Self-Compassion Scale } \\
\text { (SCS) } \\
\text { Beck Depression } \\
\text { Inventory-II (BDI-II), the } \\
\text { German } \\
\text { Structured Clinical } \\
\text { Interview for DSM-IV } \\
\text { Axis I Disorders (SCID-I; } \\
\text { German version) }\end{array}$ & $\begin{array}{l}\mathrm{N}=125 \text { depressed } \\
\text { outpatients after a time } \\
\text { limited } \\
\text { cognitive-behavioral } \\
\text { psychotherapy } \\
(54 \% \text { female })\end{array}$ & $\begin{array}{l}\text { Lack of self-compassion } \\
\text { predicts depression, } \\
\text { whereas depression does } \\
\text { not predict } \\
\text { self-compassion. This was } \\
\text { also the case for the } \\
\text { relationship } \\
\text { between self-compassion } \\
\text { and the presence of a } \\
\text { major depressive episode. } \\
\text { The same patterns } \\
\text { also occurred when the } \\
\text { reciprocal effects for two } \\
\text { composite sub-measures } \\
\text { of either } \\
\text { positive or negative facets } \\
\text { of self-compassion were } \\
\text { separately tested. }\end{array}$ \\
\hline $\begin{array}{l}\text { Lockard et al. } \\
(2014)\end{array}$ & $\begin{array}{l}\text { Validation study } \\
\text { (Standarization } \\
\text { case study) }\end{array}$ & $\begin{array}{l}\text { To establish reliability and } \\
\text { normative } \\
\text { values on the SCS-SF for } \\
\text { individuals who are } \\
\text { receiving mental health } \\
\text { services } \\
\text { at college counseling } \\
\text { centers in hope of } \\
\text { increasing the utility of the } \\
\text { scale within } \\
\text { this setting. } \\
\text { Understanding of } \\
\text { self-compassion in clinical } \\
\text { settings. }\end{array}$ & $\begin{array}{l}\text { The Standardized Data Set } \\
\text { (SDS), Self-Compassion } \\
\text { Scale-Short Form } \\
\text { (SCS-SF) }\end{array}$ & $\begin{array}{l}\text { Participants were college } \\
\text { or university counseling } \\
\text { center clients who } \\
\text { contributed } \\
\text { data to the Center for } \\
\text { Collegiate Mental Health } \\
\text { (CCMH). Students were } \\
\text { receiving individual } \\
\text { counseling } \\
\text { from one of } 10 \text { university } \\
\text { counseling centers located } \\
\text { in six different states. A } \\
\text { total of N = } 1609 \text { clients } \\
\text { participated in the study. } \\
\text { Of the students who } \\
\text { identified } \\
\text { their gender, } 1035 \text { were } \\
\text { women ( } 69 \%), 461 \\
\text { ( } 30.7 \%) \text { were men, and } \\
\text { four } \\
\text { ( } 0.3 \%) \text { identified as } \\
\text { other. }\end{array}$ & $\begin{array}{l}\text { The SCS-SF proved to be } \\
\text { reliable for use with a } \\
\text { clinical college population, } \\
\text { evidencing strong internal } \\
\text { consistency. } \\
\text { When comparing norms } \\
\text { of the clinical student } \\
\text { population in this study } \\
\text { with general student } \\
\text { populations, it appears } \\
\text { that students seeking } \\
\text { counseling tend } \\
\text { to have lower } \\
\text { self-compassion. }\end{array}$ \\
\hline $\begin{array}{l}\text { Maheux \& Price } \\
(2015)\end{array}$ & Cross-Sectional & $\begin{array}{l}\text { The relation between } \\
\text { self-compassion and PTSD } \\
\text { symptoms using DSM IV } \\
\text { and DSM } 5 \text { criteria. }\end{array}$ & $\begin{array}{l}\text { Life Events Checklist-5 } \\
\text { (LEC-5), PTSD Checklist } \\
\text { for DSM IV (PCL-C), } \\
\text { PTSD Checklist-5 } \\
\text { (PCL-5), } \\
\text { Short Form of the } \\
\text { Self-Compassion Scale } \\
\text { (SCS-SF) }\end{array}$ & $\begin{array}{l}\text { In Sample 1, participants } \\
\text { ( } \mathrm{N} 1 / 474 \text { ) were recruited } \\
\text { from the community } \\
\text { through newspaper, } \\
\text { online advertisement, local } \\
\text { clinics, and the university } \\
\text { in which the research was } \\
\text { conducted. } \\
\text { Students who completed } \\
\text { the study were eligible to } \\
\text { receive financial } \\
\text { compensation as opposed } \\
\text { to course credit. The } \\
\text { sample was predominately } \\
\text { female (n = 53; men = 21) } \\
\text { with a } \\
\text { mean age of M = 23.36. } \\
\text { In Sample 2, participants } \\
\text { were recruited through an }\end{array}$ & $\begin{array}{l}\text { Self-compassion was } \\
\text { negatively correlated with } \\
\text { aggregated PTSD } \\
\text { symptoms for DSM IV } \\
\text { land DSM } \\
\text { 5. Self-compassion was } \\
\text { correlated with avoidance } \\
\text { symptoms for DSM IV but } \\
\text { was correlated with all } \\
\text { symptom clusters for the } \\
\text { DSM } 5 \text {. }\end{array}$ \\
\hline
\end{tabular}




\begin{tabular}{|c|c|c|c|c|c|}
\hline & & & & $\begin{array}{l}\text { online crowdsourcing } \\
\text { platform } \\
\text { (Amazon's Mechanical } \\
\text { Turk). Approximately half } \\
\text { women }(\mathrm{n}=75) \text { and men } \\
(\mathrm{n}=77) \text { mean age of } \mathrm{M}= \\
35.02\end{array}$ & \\
\hline $\begin{array}{l}\text { Maheux \& Price } \\
\text { (2016) }\end{array}$ & Cross-Sectional & $\begin{array}{l}\text { Tested the hypothesis that } \\
\text { the association between } \\
\text { social support and } \\
\text { post-traumatic stress } \\
\text { disorder (PTSD), } \\
\text { generalised anxiety } \\
\text { disorder (GAD), and } \\
\text { depression symptoms had } \\
\text { an indirect pathway via } \\
\text { self-compassion. }\end{array}$ & $\begin{array}{l}\text { Life Events Checklist-5 } \\
\text { (LEC-5), PTSD } \\
\text { Checklist-5 (PCL-5), } \\
\text { Patient Health } \\
\text { Questionnaire-8 (PHQ-8), } \\
\text { Generalized Anxiety } \\
\text { Disorder-7 (GAD-7), } \\
\text { Short Form of the } \\
\text { Self-Compassion Scale } \\
\text { (SCS-SF), The } \\
\text { Multidimensional Scale of } \\
\text { Perceived Social Support } \\
\text { (MSPSS) }\end{array}$ & $\begin{array}{l}\text { Participants }(\mathrm{N}=599) \\
\text { were recruited through an } \\
\text { online crowdsourcing } \\
\text { platform (Amazon's } \\
\text { Mechanical Turk) and } \\
\text { were required to have } \\
\text { experienced a Criterion A } \\
\text { traumatic } \\
\text { event to be included in the } \\
\text { study. }\end{array}$ & $\begin{array}{l}\text { Social support } \\
\text { was positively related to } \\
\text { self-compassion. } \\
\text { Self-compassion was } \\
\text { negatively related to } \\
\text { PTSD, GAD, and } \\
\text { depression } \\
\text { symptoms. } \\
\text { Self-compassion mediated } \\
\text { the relation between social } \\
\text { support and PTSD, GAD, } \\
\text { and depression symptoms. }\end{array}$ \\
\hline Miron et al. (2016) & Cross-Sectional & $\begin{array}{l}\text { To see if survivors of } \\
\text { childhood sexual abuse } \\
\text { exhibit fear of } \\
\text { self-compassion and } \\
\text { whether it relates to } \\
\text { psychological functioning. } \\
\text { The present model } \\
\text { examined pathways from } \\
\text { childhood physical and } \\
\text { sexual abuse to symptoms } \\
\text { of PTSD and depression } \\
\text { through self-compassion } \\
\text { and fear of } \\
\text { self-compassion. }\end{array}$ & $\begin{array}{l}\text { Traumatic Life Events } \\
\text { Questionnaire (TLEQ), } \\
\text { Post traumatic stress } \\
\text { disorder screening and } \\
\text { diagnostic scale (PSDS), } \\
\text { Depression, Anxiety and } \\
\text { Stress Scale (Dass-21), } \\
\text { Self-Compassion Scale } \\
\text { (SCS), Fear of } \\
\text { Self-compassion } \\
\text { scales-Self-compassion } \\
\text { (FCS-SC) }\end{array}$ & $\begin{array}{l}\text { A college sample }(\mathrm{N}= \\
377) . \text { Inclusion criteria was } \\
\text { fluency in English and } \\
\text { age }>18 . \text { Mean age was } \\
19.12 \text { years old. }\end{array}$ & $\begin{array}{l}\text { Significant indirect effect } \\
\text { sof childhood sexual abuse } \\
\text { on symptoms of } \\
\text { depression and PTSD via } \\
\text { fear of self-compassion but } \\
\text { not self-compassion. }\end{array}$ \\
\hline $\begin{array}{l}\text { Potter et al. } \\
(2014)\end{array}$ & Cross-sectional & $\begin{array}{l}\text { To test if social anxiety is } \\
\text { associated with } \\
\text { parental criticism and } \\
\text { examine the } \\
\text { possibility that different } \\
\text { aspects of self-compassion } \\
\text { (self-warmth and } \\
\text { self-coldness) } \\
\text { mediate the relationship } \\
\text { between parental criticism } \\
\text { and social anxiety. }\end{array}$ & $\begin{array}{l}\text { Frost Multidimensional } \\
\text { Perfectionism Scale } \\
\text { (FMPS), The } \\
\text { Self-Compassion Scale, } \\
\text { The Liebowitz Social } \\
\text { Anxiety Scale (LSAS) }\end{array}$ & $\begin{array}{l}\text { The sample consisted of } \\
\mathrm{n}=140 \text { females and } \mathrm{n}=71 \\
\text { males ranging from } 18 \text { to } \\
63 \text { years of age } \\
(\mathrm{M}=30.23) \text {. They were } \\
\text { recruited from the general } \\
\text { population and were } \\
\text { offered an } \\
\text { entry into a lucky draw } \\
\text { prize as incentive for } \\
\text { participating. }\end{array}$ & $\begin{array}{l}\text { Both self-warmth and } \\
\text { self-coldness } \\
\text { components of } \\
\text { self-compassion mediated } \\
\text { the relationship between } \\
\text { parental criticism and } \\
\text { social anxiety. Individuals } \\
\text { who reported being } \\
\text { frequently criticized by } \\
\text { parents were more likely } \\
\text { to } \\
\text { have low self-compassion, } \\
\text { which in turn was } \\
\text { associated with higher } \\
\text { social anxiety. }\end{array}$ \\
\hline $\begin{array}{l}\text { Psychogiou et al. } \\
\text { (2016) }\end{array}$ & $\begin{array}{l}\text { Study 1: a pilot } \\
\text { trial of } \\
\text { mindfulness-based } \\
\text { cognitive } \\
\text { therapy } \\
\text { Study 2: a } \\
\text { longitudinal study }\end{array}$ & $\begin{array}{l}\text { To examine whether } \\
\text { higher levels of } \\
\text { d self-compassion were } \\
\text { associated with better } \\
\text { parenting and fewer } \\
\text { emotional and behavioral } \\
\text { problems in children of } \\
\text { parents with a history of } \\
\text { depression. }\end{array}$ & $\begin{array}{l}\text { The Self-Compassion Scale } \\
\text { (SCS), Structured Clinical } \\
\text { Interview for DSM-IV, } \\
\text { The Beck Depression } \\
\text { Inventory Second Edition } \\
\text { (BDI-II), Parents' } \\
\text { Sensitive Responding } \\
\text { Interactions were } \\
\text { video-recorded and were } \\
\text { coded later using }\end{array}$ & $\begin{array}{l}\text { eStudy 1: } 38 \text { parents with } \\
\text { recurrent depression. } \\
\text { ( } 36 \text { mothers and } 2 \text { fathers, } \\
\text { mean age = } 36.2 \text { years) } \\
\text { Study 2: } \\
160 \text { families, including } 50 \\
\text { mothers and } 40 \text { fathers } \\
\text { who had a } \\
\text { history of depression. }\end{array}$ & $\begin{array}{l}\text { Study 1: } \\
\text { Parents reporting higher } \\
\text { levels of } \\
\text { self-compassion were } \\
\text { more likely to attribute the } \\
\text { cause of } \\
\text { their children's behavior } \\
\text { to external factors, were } \\
\text { less critical, } \\
\text { and used fewer distressed }\end{array}$ \\
\hline
\end{tabular}




\begin{tabular}{|c|c|c|c|c|c|}
\hline & & & $\begin{array}{l}\text { the Coding of } \\
\text { Attachment-Related } \\
\text { Parenting (CARP, Parents } \\
\text { Attributions of Their } \\
\text { Children's Behavior using } \\
\text { a measure of parental } \\
\text { attributions, developed } \\
\text { by Dadds, Scott, and } \\
\text { Woolgar at the National } \\
\text { Academy of } \\
\text { Parenting Research } \\
\text { (NAPR, UK) }\end{array}$ & & $\begin{array}{l}\text { reactions to cope with } \\
\text { their children's } \\
\text { emotions. } \\
\text { Study 2: } \\
\text { Greater self-compassion } \\
\text { was associated with lower } \\
\text { levels of mothers' } \\
\text { child-directed criticism } \\
\text { and fathers' distressed } \\
\text { reac- tions. }\end{array}$ \\
\hline Reid et al. (2014) & Cross-sectional & $\begin{array}{l}\text { To examine factors that } \\
\text { may attenuate } \\
\text { the negative impact that } \\
\text { shame and rumination } \\
\text { may have on } \\
\text { hypersexuality. }\end{array}$ & $\begin{array}{l}\text { Hypersexual Behavior } \\
\text { Inventory (HBI), Shame } \\
\text { Inventory (SI), } \\
\text { Self-Rumination Scale } \\
\text { (SRS), Self-Compassion } \\
\text { Scale-Short Form (SCS) }\end{array}$ & $\begin{array}{l}\mathrm{N}=172 \text { men who were } \\
\text { recruited during a DSM-5 } \\
\text { field trial investigating } \\
\text { the proposed diagnosis of } \\
\text { hypersexual disorder. The } \\
\text { participants were } \\
\text { consecutively } \\
\text { selected at outpatient } \\
\text { clinics based on 1) a } \\
\text { primary } \\
\text { complaint of hypersexual } \\
\text { behavior reported during } \\
\text { intake and 2) willingness } \\
\text { to participate in and } \\
\text { consent } \\
\text { to the research protocol. } \\
\text { All patients in this } \\
\text { study met the DSM-5 } \\
\text { proposed diagnostic } \\
\text { criteria for } \\
\text { HD. }\end{array}$ & $\begin{array}{l}\text { Self-compassion partially } \\
\text { mediated } \\
\text { the relationship between } \\
\text { shame and rumination } \\
\text { and hypersexual behavior. }\end{array}$ \\
\hline $\begin{array}{l}\text { Scoglio et al. } \\
\text { (2015) }\end{array}$ & Cross-Sectional & $\begin{array}{l}\text { To explore the } \\
\text { interconnection among } \\
\text { self-compassion, } \\
\text { resilience, emotion } \\
\text { dysregulation, } \\
\text { and PTSD symptom } \\
\text { severity in a sample of } \\
\text { treatment-seeking women } \\
\text { with } \\
\text { PTSD. }\end{array}$ & $\begin{array}{l}\text { Symptoms of PTSD were } \\
\text { assessed using the CAPS, a } \\
\text { semistructured clinical } \\
\text { interview } \\
\text { drawn from the symptoms } \\
\text { described in the } \\
\text { Diagnostic and Statistical } \\
\text { Manual } \\
\text { of Mental Disorders (4th } \\
\text { ed.; DSM-IV), } \\
\text { Self-Compassion } \\
\text { Scale-Short Form } \\
\text { (SCS-SF), Difficulties in } \\
\text { Emotion Regulation Scale } \\
\text { (DERS), } \\
\text { Connor-Davidson } \\
\text { Resilience Scale } \\
\text { (CD-RISC). }\end{array}$ & $\begin{array}{l}\mathrm{N}=176 \text { participants from } \\
\text { a a larger ongoing multisite } \\
\text { clinical } \\
\text { trial, which recruited } \\
\text { s women ages } 18 \text { to } 65 \\
\text { (mean age of } 41.18 \text { ), in } \\
\text { four large public hospitals } \\
\text { in urban } \\
\text { settings. Participants were } \\
\text { female survivors } \\
\text { of interpersonal violence } \\
\text { (physical or sexual } \\
\text { violence) with a primary } \\
\text { diagnosis } \\
\text { of PTSD. }\end{array}$ & $\begin{array}{l}\text { Self-compassion was } \\
\text { negatively related to PTSD } \\
\text { symptom severity and to } \\
\text { emotion dysregulation, } \\
\text { and positively related to } \\
\text { resilience. In addition, } \\
\text { emotion } \\
\text { dysregulation mediated } \\
\text { the relationship between } \\
\text { PTSD symptom severity } \\
\text { and self-compassion and } \\
\text { also influenced the } \\
\text { relationship between } \\
\text { resilience and } \\
\text { self-compassion. }\end{array}$ \\
\hline $\begin{array}{l}\text { Trompetter et al. } \\
\text { (2016) }\end{array}$ & Cross-Sectional & $\begin{array}{l}\text { To examine if } \\
\text { self-compassion functions } \\
\text { as a resilience mechanism } \\
\text { and adaptive emotion } \\
\text { regulation strategy that } \\
\text { protects against } \\
\text { psychopathology } \\
\text { for those with high levels }\end{array}$ & $\begin{array}{l}\text { The Mental Health } \\
\text { Continuum-Short Form } \\
\text { (MHC-SF), The } \\
\text { Self-Compassion } \\
\text { Scale-Short Form } \\
\text { (SCS-SF), The Hospital } \\
\text { Anxiety Depression Scale } \\
\text { (HADS), The modified }\end{array}$ & $\begin{array}{l}\text { Sample consisted of } \\
\mathrm{N}=349 \text { participants who } \\
\text { filled } \\
\text { out an online survey. This } \\
\text { was a convenience sample. } \\
\text { Of the } 349 \text { participants, } \\
64.5 \% \text { was female. Mean } \\
\text { age of }\end{array}$ & $\begin{array}{l}\text { Self-compassion } \\
\text { significantly mediated the } \\
\text { negative relationship } \\
\text { between } \\
\text { positive mental health and } \\
\text { psychopathology. Higher } \\
\text { levels of self-compassion } \\
\text { attenuated the relationship }\end{array}$ \\
\hline
\end{tabular}


of positive mental health. Differential Emotions Scale (mDES)

Waite et al. (2015)

Werner et al. (2012)

Wetterneck et al. Cross-sectional (2013)

Xavier et al. (2016) Cross-Sectional
To examine self-compassion and its correlates in a treatment-seeking sample of persons with social anxiety disorder (SAD). (LSAS), The Social (BFNE), The Fear of Inventory II (BDI-II), Spielberger State Trait Anxiety Inventory (STAI-T) OCD show Inventory-Revised deficits in the specific (OCI-R), Yale-Brown values of self-compassion Obsessive Compulsive and courage, and Scale: Self-Report the extent to which they are living in accordance with their overall (Y-BOCSSR), Courage Self-Compassion Scale values. Also, to explore the (SCS), Valued Living relationship between Questionnaire (VLQ). OCD severity and one's overall valued living as well as the personal values of self-compassion and courage.

To test whether specific the participants was 32.88 . between state negative affect and psychopathology. Self-criticism maintained distressing experiences professionals from a community mental of psychosis and health team in the United compassionate Kingdom identified self-acceptance resulted in potential participants empowered action and $(\mathrm{N}=10)$, between 25 and promoted 52 years $($ mean $=35.8 \quad$ recovery and growth. The years)

The age of onset of and change in relationship psychosis ranged from 16 to self was central to to 43 years $($ mean $=22.8$ recovery. years).

Working diagnoses (noted from existing medical records) included paranoid schizophrenia, schizotypal disorder, and schizophrenia with secondary depression.

The Self-Compassion ScaleN = 72 (33 men, $39 \quad$ People with SAD reported (SCS), The Liebowitz women) with generalised less self-compassion, but it Social Anxiety Scale SAD (mean age 33.8) wasn't generally associated Interaction Anxiety Scale (SIAS), The Brief Fear of Negative Evaluation Scale Positive Evaluation Scale (FPES), Beck Depression

To examine if people with Obsessive-Compulsive measure (CM), internal traits

The Other as Shamer Scale The sample was collected (OAS2), The Fears of from middle and

External shame, hated self

characterized by shame, Compassion Scales, The self-criticism and fear of Forms of secondary schools in the district of and fear of self-compassion indirectly predict NSSI, self-compassion impact on Self-Criticism/Self-ReassurCoimbra, Portugal. through their effect in Non-suicidal self-injury ing Scale (FSCRS), The $\quad \mathrm{N}=782$ adolescents, 369 daily peer hassles and (NSSI), through their Daily Hassles Microsystemboys (47.2\%) and 413 girls depression. Strong link 


$\begin{array}{llll}\text { effect in daily } & \text { Scale (DHMS), The } & (52.8 \%) \text {. Age ranged } & \text { between hated self and } \\ \text { peer hassles and } & \text { Depression Anxiety and } & \text { between } 12 \text { and } 18 \text { years } & \text { NSSI. } \\ \text { depression. } & \text { Stress Scales (DASS-21), } & \text { old }(\mathrm{M}=14.89) . & \\ & \text { The risk-taking and } & & \\ & \text { self-harm inventory for } & & \\ & \text { adolescents (RTSHIA) all } \\ & \text { in Poruguese. }\end{array}$

study examining people with obsessive-compulsive disorder (OCD), a significant relationship was found between symptom severity and values in life with the values of self-compassion and courage (Wetterneck et al., 2013). Also, less self-compassion was reported by another study, trying to investigate self-compassion and its correlations, in a sample of persons with social anxiety disorder (SAD). Results indicated that while people with SAD had less self-compassion, it didn't amount to worse symptoms even though it did bring up a greater fear of any kind of evaluation (Werner et al., 2012).

Another study asserted that self-compassion acts as a buffer against ruminating events that have already happened, something common for people with social anxiety (Blackie \& Kocovski, 2017) and something similar was also argued in another study too (Cândea \& Szentágotai-Tătar, 2018). The same authors (Blackie \& Kocovski, 2017) later found that self-compassion can be used to reduce negative and repetitive thinking, so as people with social anxiety will continue having a social life.

Social anxiety and low self-compassion have also been found in people who were brought up by critical parents (Potter et al., 2014).

As far as families and anxiety are concerned, another research $(\mathrm{N}=500)$, indicated that families chaotically-enmeshed appeared to have lower flexibility and self-compassion, too (Berryhill, Hayes, \& Lloyd, 2018).

\subsection{Self-Compassion and Depression}

Low self-compassion is reported in patients with remitted Bipolar Disorder (BD) and their life satisfaction appears to be reduced (Døssing et al., 2015). These findings, as some of other studies' (Diedrich et al., 2014; Diedrich et al., 2016; Krieger et al., 2016) bring forward that there's probably a connection between self-compassion and depressive symptoms and self-compassion can be an effective emotion regulation strategy in patients with major depressive disorder. In a longitudinal design study (Krieger et al., 2016) examining the association between depression and self-compassion, the findings indicate that lack of self-compassion is a significant vulnerability factor for depressive symptoms and even a major depressive episode, without necessarily causing depression though.

As far as depression is concerned, a different paper written about two independent studies, a pilot study and a longitudinal one, trying to examine if parents with depression do better at parenting when they're self-compassionate and how this reflects on their children's behaviors, found that parents with higher levels of self-compassion were less critical, they could cope better with their kids' 
emotions and didn't attribute everything to their own doings (Psychogiou et al., 2016).

A Self-Criticism/Compassion Mediation Model was constructed for another study (Joeng \& Turner, 2015) with university students, which tried to investigate the relationships between internalized self-criticism and depression and the results indicated that self-compassion partially mediated both the relationship between internalized self-criticism and depression, and the relationship between comparative self-criticism and depression.

\subsection{Self-Compassion and General Diagnoses of Psychopathology}

Another clinical sample, with schizophrenia spectrum disorders this time, was studied by Eicher et al. (2013) and the results show that self-compassion and psychopathology are indeed correlated and the higher the self-compassion the lower the discomfort patients felt with their symptoms. In the same light, a study with a clinical sample of people diagnosed with psychosis, indicated that greater narrative compassion is linked to less negative symptoms, less cognitive disorganization and less excitement (Gumley \& Macbeth, 2014). To recover from a psychotic episode is a difficult process but it can get a little easier to handle when patients practise self-compassionate self-acceptance, highlights a qualitative study by Waite et al. (2015).

A recent study (Collett et al., 2016) showed that self-compassion is really low in persons with persecutory delusions, as is their self-esteem and feeling of inferiority. Negative cognitions and decreased positive beliefs are also high in this group. Next, a randomized pilot study intervention with people experiencing borderline personality disorder, shows that three weeks of loving-kindness and compassion meditations had a significant effect on the participants, with their symptoms clearly improving. Self-criticism was lower and self-kindness levels were raised (Feliu-Soler et al., 2016).

\subsection{Self-Compassion and Post-Traumatic Stress Disorder (PTSD)}

The next studies have to do with post-traumatic stress disorder (PTSD) and self-compassion. In the first of them (Hoffart et al., 2015) it was recognised that people with PTSD symptoms were affected by self-compassion and that even though the kind of therapy plan didn't seem to have an effect on PTSD, the within-person relationship between self-judgment and subsequent PTSD symptoms was stronger in patients with higher initial self-judgment.

Maheux \& Price (2015) examined if self-compassion can act as a protector for PTSD symptoms after exposure to traumatic events and found significant correlations indicating that it might be so. They did another research after that (Maheux \& Price, 2016), investigating the relationship between social support and an increased sense of self-compassion as facilitators for recovery in PTSD and discovered a positive relation between social-support and self-compassion, while negative correlations between self-compassion and PTSD, GAD and depression 
symptoms.

Another study revealed that survivors of childhood sexual abuse show a fear of being self-compassionate and an indirect effect of childhood sexual abuse on symptoms of depression and PTSD (Miron et al., 2016).

Furthermore, a study with women with PTSD asserted that PTSD symptoms were negatively related to self-compassion, as was emotion dysregulation, and positively related to resilience (Scoglio et al., 2015). Similar results were found in another research too, listing that higher levels of self-compassion reduced the relationship between state negative affect and psychopathology, suggesting that they can work as a resilience mechanism against psychopathology (Trompetter et al., 2016).

\subsection{Self-Compassion, Internalized Self-Criticism, Fear of Self-Compassion and Shame}

A study with a sample of men with hypersexual behavior, shows that self-compassion partially mediated the relationship between shame and rumination and hypersexual behavior, normalizing the effect on people's suffering, seeing it as part of the human condition (Reid et al., 2014). A different study, trying to establish reliability and normative values on the SCS-SF (Self-Compassion Scale - Short Form) for a clinical sample found that college students who came for help in counseling centers had lower self-compassion (Lockard et al., 2014).

Emotional processing, mindfulness and the ability to have empathy towards other people, as compassion for yourself, found to be negatively correlated with a fear of compassion from others and for self. On the same note, self-criticism had a positive correlation with fears of compassion and happiness, as had depression, anxiety and stress (Gilbert et al., 2012).

Finally, a study with a sample of adolescents who had reported non-suicidal self-injury (NSSI), brought evidence that everyday experiences of external shame, hated self and fear of self-compassion indirectly predict NSSI and there was a strong connection between hated self and NSSI (Xavier et al., 2016).

\subsection{Self-Compassion and Therapy Interventions}

Last but not least, one study takes a look in alcohol dependent individuals and how they're influenced by the concept of self-compassion. Participants in this study didn't experience as much mindfulness, common humanity and self-kindness as the people in the general population. After a 15 weeks follow-up though, in which participants had undergone treatment for their dependency, they were able to report an improvement in depression, anxiety and alcohol use, which was accompanied by a significant increase in self-compassion, mindfulness, common humanity and self-kindness (Brooks et al., 2012). In another research, participants in a combined Cognitive Behavioural Therapy (CBT) and Compassionate Mind Training (CMT) reported significantly higher self-compassion scores post-therapy (Beaumont et al., 2012). Even when there's a more serious 
psychopathology involved, like that of a sample recovering from psychosis, Compassion focused therapy (CFT) helped people be more self-compassionate and lower their depression levels and had a better general outcome than the usual treatment (Braehler et al., 2013).

\section{Discussion}

\subsection{Self-Compassion and Anxiety Disorders}

Hoge et al. (2013) revealed that Generalized Anxiety Disorder (GAD) patients reported lower mindfulness and self-compassion levels than the control group of healthy adults. This is an important finding, as it shows how self-compassion and specifically mindful awareness can help people with GAD cope better with the perceived ideas of their disability, even though just one measure of disability was used (the Sheehan Disability Scale, SDS). The anxiety and worry levels of patients with GAD were significantly higher so the authors thought that if the patients learn to accept the reality of their symptoms without focusing negatively on them, this might lead them to live better, despite their symptomatology.

The same can be said for people with Obsessive-Compulsive Disorder (OCD) and social anxiety (SAD). The study with the SAD clinical sample insinuates that one of the reasons one might develop social anxiety could be low self-compassion and specifically harsh self-judgment and over-identification with one's shortcomings (Werner et al., 2012). However, because of the design of the study, causality cannot be ensured. Mindfulness and self-compassion interventions should be further explored concerning anxiety disorders treatment, as one can imagine that treating oneself kindly when in need or when in frustration, can adhere to ease and calm.

Another study asserted that self-compassion acts as a buffer against ruminating events that have already happened, something common for people with social anxiety (Blackie \& Kocovski, 2017a) and something similar was also argued in another study too (Cândea \& Szentágotai-Tătar, 2018). The same authors (Blackie \& Kocovski, 2017b) later found that self-compassion can be used to reduce negative and repetitive thinking, so as people with social anxiety will continue having a social life.

As far as families go, children of critical parents had lower self-compassion and were more self-judgmental. They also found that parental criticism was positively connected to social anxiety which can be interpreted like an after-effect of the high criticism these kids have already felt from their family, which is supported by Gilbert et al.'s (2011) finding, that a fear of self-compassion was associated with self-criticism and insecure attachment (Potter et al., 2014). As far as families and anxiety are concerned, another research $(\mathrm{N}=500)$, indicated that families chaotically-enmeshed appeared to have lower flexibility and self-compassion, too (Berryhill, Hayes, \& Lloyd, 2018). It would be interesting to do a replication with other mental health issues and perhaps a lot can be tested out with the way families operate (Psychogiou et al., 2016). 
There has also been a study where a connection was made between self-compassion and emotional invalidation and their role on psychopathology. Promising findings were shown for the application of self-compassion (Westphal, Leahy, Pala, \& Wupperman, 2016).

\subsection{Self-Compassion and Depression}

Diedrich et al. (2014) revealed that self-compassion could be used with success as another adaptive emotion regulation strategy for patients with major depressive disorder, especially for those suffering from high levels of a depressed mood. Later, Diedrich et al. (2016) showed that self-compassion can enhance the efficacy of explicit cognitive reappraisal as an emotion regulation strategy in individuals with major depressive disorder and even though cognitive reappraisal sometimes is hard to be achieved by people with depression, self-compassion could work as a preparation for it and with good results. Krieger et al. (2016) found that lack of self-compassion is a predictor of depressive symptomatology even though the reverse doesn't happen. This is an important finding on one hand, but on the other they still cannot claim a causal relationship, as the study hasn't clearly investigated other mediators. However, one can argue that it is possible to cultivate compassion as other studies have shown. These studies (Diedrich et al., 2014; Krieger et al., 2016) bring forward that there is possibly a connection between self-compassion and depressive symptoms though the kind of relationship and how self-compassion results to the onset and maintenance of the symptoms of depression isn't yet crystal clear. Thus, it is of great importance to research the role of low self-compassion in the emergence and maintenance of depressive symptoms and see its relevance to treatment and life-satisfaction (Døssing et al., 2015).

Yet another study agrees that self-criticism and depression are linked and gives away that people who are self-critical are those who need more to be self-compassionate and can benefit greatly from that. To manage to see their imperfections as part of their common humanity could be very helpful for these individuals and while it could take too long to completely understand how self-criticism and fear of compassion limits their lives, until then, they might benefit greatly by therapists who can teach them how to be kinder with themselves (Joeng \& Turner, 2015).

\subsection{Self-Compassion and General Diagnoses of Psychopathology}

Additionally, in a sample with Borderline Personality Disorder undergoing a short training program in loving-kindness and compassion meditation (LKM/CM) symptoms were seriously improved as well as their acceptance, self-criticism and mindfulness (Feliu-Soler et al., 2016). Even though this is the first study to examine something like that, teaching LKM/CM to patients with BPD appears to be a valid choice with potentially great results for more kindness towards oneself and less judgement. Neff (2011) has already argued that love and 
wanting to take care of oneself isn't compatible with negative feelings of harshness and non-acceptance, so this study seems to be congruent with previous indications.

Patients with persecutory delusions also had low self-compassion and feelings of inferiority, along with low self-esteem and low mood. Unexpectedly, self-stigma was quite on the same levels between the two groups (control group/persecutory delusions group) but the size of the sample might be the case for that. Suicidal ideation in the group with persecutory delusions was also high. This study too, brings forward that negative self-concept in patients with persecutory delusions are a clear treatment target, so self-compassion learning, through Compassion Focused Therapy (CFT) or as part of another therapy treatment could be suitable and help ease the negativity surrounding the delusions. Of course, because of the study design, it isn't possible to see cause and effect. Future longitudinal studies research with larger sample sizes should be conducted (Collett et al., 2016). A very recent study study (Heath, Brenner, Lannin, \& Vogel, 2018) with a sample of 369 subjects showed that self-stigma is moderated through self-compassion and that self-compassion might be a protective factor for the public stigma as well as self-stigma for those that seek psychological help.

Even though Gumley \& Macbeth (2014) hypothesized that narrative compassion would correlate with the Self-Compassion Scale in individuals with psychosis, they didn't find such a thing, but it might have to do with the small size sample. However, greater narrative compassion was associated with less negative symptoms, less cognitive disorganization and less excitement, adding to the general recognition that raised compassion for oneself and others can protect someone from feelings of threat, shame, humiliation and paranoia. Adding to the theory that CFT (Braehler et al., 2013) could help cultivating compassion in people with psychotic symptoms, this study argues that an attachment-based understanding of compassion, and specifically the domains of safe haven and secure base, could add to recovery from this kind of mental health problems (Gumley \& Macbeth, 2014).

Another study (Eicher et al., 2013) with patients with schizophrenia or schizoaffective disorder highlighted that there was a negative relationship between self-compassion and measures of insight. Analysis of the findings indicated that those who had a better awareness of their situation had also higher levels of self-judgement, isolation and over-identification. That higher insight seems to be linked to lower self-compassion isn't very encouraging, if self-compassion is seen as a trait-like feature. However, if self-compassion is seen from a learning standpoint there is room for improvement for everyone and compassionate mind training could really help these kinds of samples too (Gilbert \& Irons, 2005). Individuals that are taught how to accept their reality better and treat themselves with kindness and compassion might not manage a disappearance of their symptoms but a might have a better chance of peace and life satisfaction. 
This is congruent with mindfulness as Kabat-Zinn (1990) sees it, which has to do with a great emphasis on accepting the present experience, regardless of whether the experience is pleasant, unpleasant or neutral.

Another systematic review (Inwood \& Ferrari, 2018) found a promising link between self-compassion and emotion regulation, with self-compassion acting as a base to amplify people's ability to experience their feelings.

Finally, a recent study (Kraiss et al., 2018) used positive psychology tools for assertion of the well-being of bipolar patients and self-compassion seemed to really make a difference in that.

\subsection{Self-Compassion and Post-Traumatic Stress Disorder (PTSD)}

Victims of childhood abuse also had lower self-compassion and fear of self-compassion. This fear might have to do with trauma pathology the paper suggests, and possibly higher self-compassion protects one from trauma (Miron et al., 2016). Two more studies (Maheux \& Price, 2015; Maheux \& Price, 2016) bring forward that self-compassion can be an antidote to PTSD symptom severity while a lack of it might be a factor of maintaining PTSD (Hoffart et al., 2015). Another study claims that social support can be extremely helpful for PTSD sufferers and that self-compassion protects from GAD and depression along with PTSD. It isn't known though, if social support acts proactively as a protector from PTSD or if lack of it would be a risk factor (Maheux \& Price, 2016).

Going further, a study examining PTSD symptom severity in traumatized women, supported the existing literature by showing that self-compassion was negatively related to PTSD symptom severity and to emotion dysregulation and positively related to resilience (Scoglio et al., 2015). This study indicates that self-compassion can be used as a resilience mechanism, something that is also supported by Trompetter et al. (2016) whose findings suggest that individuals with high levels of positive mental health possess self-compassion skills that promote resilience against psychopathology.

Last but not least, a recent study (Barlow, Goldsmith, Turow, \& Gerhart, 2017) showed significant relations between negative trauma appraisals, childhood abuse, PTSD symptoms and self-compassion, in a sample of 466 university non-clinical students.

\subsection{Self-Compassion, Internalized Self-Criticism, Fear of Self-Compassion and Shame}

Given that most studies examining self-compassion use the standard Self-Compassion Scale and given that so many papers argue the importance of self-compassion for psychological health (Barnard \& Curry, 2011; MacBeth \& Gumley, 2012) there was a need to find out about the reliability of the SCS to a clinical sample. Lockard et al. (2014) did so with a large sample of university students and confirmed that. They also found no significant differences between race/ethnicity, sexual orientation, and gender. An important finding was that 
students who asked for help had low self-compassion levels, same as depressed adults. This is one more study indicating the importance self-compassion could have in a therapeutic setting and also one more study that shows that low levels of self-compassion might lead someone to seek counselling (even if it hasn't to do with serious psychopathology).

There have been several papers (Gilbert et al., 2012; Gilbert, McEwan, Matos et al., 2011) investigating the potential relationship between people's abilities to experience and tolerate positive emotions and how this connects to psychopathology. Gilbert et al.'s study (2012) takes this a step further by creating a new scale to measure fear of happiness and examines how it connects to fear of self-compassion, alexithymic traits, mindfulness, and empathy. Fears of positive affect scales (e.g., compassion and happiness) significantly linked to psychopathology and there was also a very high correlation between fear of happiness and depression. Fears of compassion were associated to depression, anxiety and stress, something that has already been explored from the literature (Gilbert, McEwan, Matos et al., 2011; Gilbert et al., 2012).

Reid et al. (2014) studied men with hypersexual behavior and tried to investigate if shame and rumination in these men was mediated by self-compassion. Results indicated that shame and negative feelings were indeed made easier to accept by cultivating self-compassion.

Compassion focused therapy was also found to be an important asset to the minimization of fear of self-compassion and psychopathology which is an indication for the future of therapy in clinical populations (Cuppage et al., 2018).

Finally, Xavier et al. (2016) supported that adolescents with Non-suicidal self-injury (NSSI) are highly self-critical and have feelings of shame and fear of self-compassion while they tend to punish themselves when they fail or don't do very well. Self-compassion could probably be a great addition to these teens' lives, helping them to incorporate their experience as the human condition and that failing is human.

\subsection{Self-Compassion and Therapy Interventions}

One of the first studies to examine self-compassion in a sample with alcohol dependence revealed that the participants were also experiencing depression and anxiety at higher levels than the general population (Brooks et al., 2012). Neff (2003a) has previously found that self-compassion is inversely related to depression and anxiety, something that this study confirms. What is striking in this study is that while participants with alcohol dependence were feeling more isolated and did harshly self-judge, they were also kinder to themselves, something that might had to do with using alcohol as a self-soothing technique. This has to be further researched to see if it is indeed so. Even so, participants reported greater self-compassion in the follow-up assessment and reductions in anxiety and stress. Future studies could benefit from a mindfulness intervention in a longitudinal design, to see how it interacts with that kind of sample. 
A similar study, this time with Australian psychology trainees, with a pre-experimental repeated-measures design, asserted that online self-compassion training had a positive effect on the subjects' feelings of happiness and self-compassion, while depression and stress were decreased (Finlay-Jones, Kane, \& Rees, 2017).

Beaumont et al., 2012, designed a prospective comparative study in which two different groups underwent therapy for a trauma related incident with the same therapist, but while one group experienced Compassionate Mind Training (CMT) the other just have some typical Cognitive Behavioural Therapy (CBT) sessions. Even though the authors expected greater differences between the two groups, there weren't that statistically semantic differences in avoidance, intrusive thoughts, hyperarousal, anxiety and depression. However, their third hypothesis, maintained that the participants in the combined CMT and CBT group would report much higher self-compassion levels and that was the outcome indeed. Even though the sample size wasn't that big $(\mathrm{N}=32)$, one can safely assume that CMT could be a useful addition to CBT when people are experiencing deep trauma.

Findings of a study (Braehler et al., 2013) with people recovering from psychosis, demonstrate that Compassion Focused Therapy (CFT) could be very useful even when there's serious psychopathology involved. CFT appears to be a suitable intervention for people recovering from psychosis, helping them to turn off their inner judge and making the handling of distressing voices or internal threats more bearable. CFT was initially developed for people who were unable to feel compassion for themselves (Barnard \& Curry, 2011) and people with psychosis are usually one of those groups. "A key aspect of CFT in psychosis involves helping individuals to develop a warm, caring, and attuned attitude towards difficult inner experiences”, writes Braehler et al. (2013). Other positive outcomes in the CFT group were reductions in depression, negative beliefs about psychosis, and fear of relapse. As a lot of people with such diagnoses report feeling ashamed or inferior to other people, CFT looks like it could be valuable.

Lastly, a systematic review showed that mindfulness interventions can help health care professionals to reduce stress (Burton et al., 2017).

\section{Conclusion, Limitations and Future Research}

In conclusion, this review provides useful information regarding the research of self-compassion in clinical sample. Even though most studies tend to agree that low self-compassion and psychopathology are present in clinical samples, no study until now can prove a clause for causality, as most studies were of a cross-sectional design. Future studies should use additional mediators to check out low self-compassion and mental health. Another question to be asked is if self-compassion is equally important for one's recovery as is for prevention of appearance of mental illness. From this systematic review, it cannot be known if low self-compassion is a result of psychopathology or a vulnerability factor for it. 
Of course, this is a difficult thing to prove but maybe a longitudinal study starting with people at an early age could give away the relevant info. Another thing to consider is if self-compassion can help people build resilience to psychopathology and how these two concepts are interconnected. Even though causality cannot be admitted, findings of this review make it clear that self-compassion could potentially help everyone. It probably should be a part of every person's therapy, whatever the therapeutic approach and CMT could especially help people with severe self-judgement, self-criticism, depression and metaphorical "self-beating". The "internal judge" could be turned off and a more peaceful life could be achieved. Future research could focus on a single large study to see how if this is actually the case (Germer \& Neff, 2013).

This review has its own limitations too. First of all, there was a high level of heterogeneity in the studies included. This was as true for the mental health issues involved as it was for races/ethnicities/genders/ages. A lot of papers included samples with more than one mental health issues. More studies need to be done, with the same issues of mental health and the same ages/genders (MacBeth \& Gumley, 2012). Most of the studies didn't have that large sample sizes which is a limitation for the generalization of the results, too. Another limitation was the sources of collecting data. Pubmed, Neff s website and Google scholar do not necessarily have available all the relevant studies. One more limitation is that the majority of the studies used mostly white people as a sample. It would be interesting to find out differences between countries or cultures, if there are any. Another thing that should be considered is to check for cultural factors and for gender variables and how they affect levels of self-compassion. Last but not least, there are studies that use the full SCS and others that use the short form. This might be considered a problem too, as it's not entirely sure that all self-compassion components play the same role when it comes to psychopathology and some of its factors seem to be indicative of psychopathology while others seem to be preventative, so this should be further explored for better classification and better treatment plans (Muris \& Petrocchi, 2016).

\section{Conflicts of Interest}

The author declares no conflicts of interest regarding the publication of this paper.

\section{References}

Allen, A., \& Leary, M. R. (2010). Self-Compassion, Stress, and Coping. Social and Personality Psychology Compass, 4, 107-118. https://doi.org/10.1111/j.1751-9004.2009.00246.x

American Psychiatric Association (2013). Diagnostic and Statistical Manual of Mental Disorders (5th ed.). Arlington, VA: American Psychiatric Publishing. https://doi.org/10.1176/appi.books.9780890425596

Barlow, M. R., Turow, R. E. G., \& Gerhart, J. (2017). Trauma Appraisals, Emotion Regulation Difficulties, and Self-Compassion Predict Posttraumatic Stress Symptoms Fol- 
lowing Childhood Abuse. Child abuse \& neglect, 65, 37-47.

https://doi.org/10.1016/j.chiabu.2017.01.006

Barnard, L. K., \& Curry, J. F. (2011). Self-Compassion: Conceptualizations, Correlates, \& Interventions. Review of General Psychology, 15, 289-303. https://doi.org/10.1037/a0025754

Beaumont, E., Galpin, A., \& Jenkins, P. (2012). Being Kinder to Myself: A Prospective Comparative Study, Exploring Post-Trauma Therapy Outcome Measures, for Two Groups of Clients, Receiving Either Cognitive Behaviour Therapy or Cognitive Behaviour Therapy and Compassionate Mind Training. Counseling Psychology Review, 27, 31-43.

Berryhill, M. B., Hayes, A., \& Lloyd, K. (2018). Chaotic-Enmeshment and Anxiety: The Mediating Role of Psychological Flexibility and Self-Compassion. Contemporary Family Therapy, 40, 326-337. https://doi.org/10.1007/s10591-018-9461-2

Blackie, R. A., \& Kocovski, N. L. (2017a). Examining the Relationships among Self-Compassion, Social Anxiety, and Post-Event Processing. Psychological Reports, 121, 669-689. https://doi.org/10.1177/0033294117740138

Blackie, R. A., \& Kocovski, N. L. (2017b). Forgive and Let Go: Effect of Self-Compassion on Post-Event Processing in Social Anxiety. Mindfulness, 9, 654-663.

https://doi.org/10.1007/s12671-017-0808-9

Braehler, C., Gumley, A., Harper, J., Wallace, S., Norrie, J., \& Gilbert, P. (2013). Exploring Change Processes in Compassion Focused Therapy in Psychosis: Results of a Feasibility Randomized Controlled Trial. British Journal of Clinical Psychology, 52, 199-214. https://doi.org/10.1111/bjc.12009

Braun, T. D., Park, C. L., \& Gorin, A. (2016). Self-Compassion, Body Image, and Disordered Eating: A Review of the Literature. Body Image, 17, 117-131. https://doi.org/10.1016/j.bodyim.2016.03.003

Brooks, M., Kay-Lambkin, F., Bowman, J., \& Childs, S. (2012). Self-Compassion amongst Clients with Problematic Alcohol Use. Mindfulness, 3, 308-317. https://doi.org/10.1007/s12671-012-0106-5

Burton, A., Burgess, C., Dean, S., Koutsopoulou, G. Z., \& Hugh-Jones, S. (2017). How Effective Are Mindfulness-Based Interventions for Reducing Stress among Healthcare Professionals? A Systematic Review and Meta-Analysis. Stress and Health, 33, 3-13. https://doi.org/10.1002/smi.2673

Cândea, D. M., \& Szentágotai-Tătar, A. (2018). The Impact of Self-Compassion on Shame-Proneness in Social Anxiety. Mindfulness, 9, 1816-1824.

https://doi.org/10.1007/s12671-018-0924-1

Collett, N., Pugh, K., Waite, F., \& Freeman, D. (2016). Negative Cognitions about the Self in Patients with Persecutory Delusions: An Empirical Study of Self-Compassion, Self-Stigma, Schematic Beliefs, Self-Esteem, Fear of Madness, and Suicidal Ideation. Psychiatry Research, 239, 79-84. https://doi.org/10.1016/j.psychres.2016.02.043

Cuppage, J., Baird, K., Gibson, J., Booth, R., \& Hevey, D. (2018). Compassion Focused Therapy: Exploring the Effectiveness with a Transdiagnostic Group and Potential Processes of Change. British Journal of Clinical Psychology, 57, 240-254. https://doi.org/10.1111/bjc.12162

Diedrich, A., Grant, M., Hofmann, S. G., Hiller, W., \& Berking, M. (2014). Self-Compassion as an Emotion Regulation Strategy in Major Depressive Disorder. Behaviour Research and Therapy, 58, 43-51. https://doi.org/10.1016/j.brat.2014.05.006

Diedrich, A., Hofmann, S. G., Cuijpers, P., \& Berking, M. (2016). Self-Compassion En- 
hances the Efficacy of Explicit Cognitive Reappraisal as an Emotion Regulation Strategy in Individuals with Major Depressive Disorder. Behaviour Research and Therapy, 82, 1-10. https://doi.org/10.1016/j.brat.2016.04.003

Døssing, M., Nilsson, K. K., Svejstrup, S. R., Sørensen, V. V., Straarup, K. N., \& Hansen, T. B. (2015). Low Self-Compassion in Patients with Bipolar Disorder. Comprehensive Psychiatry, 60, 53-58. https://doi.org/10.1016/j.comppsych.2015.03.010

Ehret, A. M., Joormann, J., \& Berking, M. (2014). Examining Risk and Resilience Factors for Depression: The Role of Self-Criticism and Self-Compassion. Cognition, 29, 1496-1504. https://doi.org/10.1080/02699931.2014.992394

Eicher, A. E., Davis, L. W., \& Lysaker, P. H. (2013). Self-Compassion: A Novel with Symptoms in Schizophrenia? The Journal of Nervous and Mental Disease, 201, 1-5. https://doi.org/10.1097/NMD.0b013e31828e10fa

Feliu-Soler, A., Pascual, J. C., Elices, M., Martín-Blanco, A., Carmona, C., Cebolla, A., Soler, J. et al. (2016). Fostering Self-Compassion and Loving-Kindness in Patients with Borderline Personality Disorder: A Randomized Pilot Study. Clinical Psychology \& Psychotherapy, 24, 278-286. https://doi.org/10.1002/cpp.2000

Finlay-Jones, A., Kane, R., \& Rees, C. (2017). Self-Compassion Online: A Pilot Study of an Internet-Based Self-Compassion Cultivation Program for Psychology Trainees. Journal of Clinical Psychology, 73, 797-816. https://doi.org/10.1002/jclp.22375

Germer, C. K., \& Neff, K. D. (2013). Self-Compassion in Clinical Practice. Journal of Clinical Psychology, 69, 856-867. https://doi.org/10.1002/jclp.22021

Gilbert, P., \& Irons, C. (2005) Focused Therapies and Compassionate Mind Training for Shame and Self-Attacking. In P. Gilbert (Ed), Compassion: Conceptualisations, Research and Use in Psychotherapy (pp. 263-325). London: Routledge.

Gilbert, P., McEwan, K. K., Gibbons, L. L., Chotai, S. S., Duarte, J. J., \& Matos, M. M. (2012). Fears of Compassion and Happiness in Relation to Alexithymia, Mindfulness, and Self-Criticism. Psychology and Psychotherapy: Theory, Research and Practice, 85, 374-390. https://doi.org/10.1111/j.2044-8341.2011.02046.x

Gilbert, P., McEwan, K., Mato,s M., \& Rivis, A. (2011). Fears of Compassion: Development of Three Self-Report Measures. Psychology and Psychotherapy: Theory, Research and Practice, 84, 239-255. https://doi.org/10.1348/147608310X526511

Gumley, A., \& Macbeth, A. (2014). A Pilot Study Exploring Compassion in Narratives of Individuals with Psychosis: Implications for an Attachment-Based Understanding of Recovery. Mental Health, Religion \& Culture, 17, 794-811. https://doi.org/10.1080/13674676.2014.922739

Heath, P. J., Brenner, R. E., Lannin, D. G., \& Vogel, D. L. (2018). Self-Compassion Moderates the Relationship of Perceived Public and Anticipated Self-Stigma of Seeking Help. Stigma and Health, 3, 65-68. https://doi.org/10.1037/sah0000072

Hoffart, A., Øktedalen, T., \& Langkaas, T. F. (2015). Self-Compassion Influences PTSD Symptoms in the Process of Change in Trauma-Focused Cognitive-Behavioral Therapies: A Study of within-Person Processes. Frontiers in Psychology, 6, 1273.

https://doi.org/10.3389/fpsyg.2015.01273

Hoge, E. A., Hölzel, B. K., Marques, L., Metcalf, C. A., Brach, N., Lazar, S. W., \& Simon, N. M. (2013). Mindfulness and Self-Compassion in Generalized Anxiety Disorder: Examining Predictors of Disability. Evidence-Based Complementary and Alternative Medicine, 2013, Article ID: 576258. https://doi.org/10.1155/2013/576258

Inwood, E., \& Ferrari, M. (2018). Mechanisms of Change in the Relationship between Self-Compassion, Emotion Regulation, and Mental Health: A Systematic Review. Ap- 
plied Psychology: Health and Well-Being, 10, 215-235.

https://doi.org/10.1111/aphw.12127

Joeng, J. R., \& Turner, S. L. (2015). Mediators between Self-Criticism and Depression: Fear of Compassion, Self-Compassion, and Importance to Others. Journal of Counseling Psychology, 62, 453-463. https://doi.org/10.1037/cou0000071

Kabat-Zinn, J. (1990). Full Catastrophe Living: Using the Wisdom of Your Body and Mind to Face Stress, Pain, and Illness. New York: Dell Publishing.

Keyes, C. L. M. (2005). Mental Illness and/or Mental Health? Investigating Axioms of the Complete State Model of Health. Journal of Consulting and Clinical Psychology, 73, 539-548. https://doi.org/10.1037/0022-006X.73.3.539

Kraiss, J. T., Peter, M., Chrispijn, M., Trompetter, H. R., Stevens, A. W., Neutel, E., Bohlmeijer, E. T. et al. (2018). B-Positive: A Randomized Controlled Trial of a Multicomponent Positive Psychology Intervention for Euthymic Patients with Bipolar Disorder-Study Protocol and Intervention Development. BMC Psychiatry, 18, 335.

https://doi.org/10.1186/s12888-018-1916-3

Krieger, T., Berger, T., \& Grosse Holtforth, M. (2016). The Relationship of Self-Compassion and Depression: Cross-Lagged Panel Analyses in Depressed Patients after Outpatient Therapy. Journal of Affective Disorders, 202, 39-45. https://doi.org/10.1016/j.jad.2016.05.032

Leary, M. R., Tate, E. B., Adams, C. E., Allen, A. B., \& Hancock, J. (2007). Self-Compassion and Reactions to Unpleasant Self-Relevant Events: The Implications of Treating Oneself Kindly. Journal of Personality and Social Psychology, 92, 887-904.

https://doi.org/10.1037/0022-3514.92.5.887

Lockard, A. J., Hayes, J. A., Neff, K. D., \& Locke, B. D. (2014). Self-Compassion among College Counseling Center Clients: An Examination of Clinical Norms and Group Differences. Journal of College Counseling, 17, 249-259. https://doi.org/10.1002/j.2161-1882.2014.00061.x

MacBeth, A., \& Gumley, A. (2012). Exploring Compassion: A Meta-Analysis of the Association between Self-Compassion and Psychopathology. Clinical Psychology Review, 32, 545-552. https://doi.org/10.1016/j.cpr.2012.06.003

Maheux, A., \& Price, M. (2015). Investigation of the Relation Between PTSD Symptoms and Self-Compassion: Comparison Across DSM IV and DSM 5 PTSD Symptom Clusters. Self and Identity, 14, 627-637. https://doi.org/10.1080/15298868.2015.1037791

Maheux, A., \& Price, M. (2016). The Indirect Effect of Social Support on Post-Trauma Psychopathology via Self-Compassion. Personality and Individual Differences, 88, 102-107. https://doi.org/10.1016/j.paid.2015.08.051

Miron, L. R., Seligowski, A. V., Boykin, D. M., \& Orcutt, H. K. (2016). The Potential Indirect Effect of Childhood Abuse on Posttrauma Pathology through Self-Compassion and Fear of Self-Compassion. Mindfulness, 7, 596-605.

https://doi.org/10.1007/s12671-016-0493-0

Muris, P., \& Petrocchi, N. (2016). Protection or Vulnerability? A Meta-Analysis of the Relations Between the Positive and Negative Components of Self-Compassion and Psychopathology. Clinical Psychology \& Psychotherapy, 24, 373-383. https://doi.org/10.1002/cpp.2005

Neff, K. (2003a). The Development and Validation of a Scale to Measure Self-Compassion. Self and Identity, 2, 223-250. https://doi.org/10.1080/15298860309027

Neff, K. (2003b). Self-Compassion: An Alternative Conceptualization of a Healthy Attitude toward Oneself. Self and Identity, 2, 85-101. 
https://doi.org/10.1080/15298860309032

Neff, K. D. (2009). The Role of Self-Compassion in Development: A Healthier Way to Relate to Oneself. Human Development, 52, 211-214. https://doi.org/10.1159/000215071

Neff, K. D. (2011). Self-Compassion, Self-Esteem, and Well-Being. Social and Personality Compass, 5, 1-12. https://doi.org/10.1111/j.1751-9004.2010.00330.x

Neff, K., Hsieh, Y., \& Dejitterat, K. (2005). Self-Compassion, Achievement Goals, and Coping with Academic Failure. Self and Identity, 4, 263-287. https://doi.org/10.1080/13576500444000317

Potter, R., Yar, K., Francis, A. J., \& Schuster, S. (2014). Self-Compassion Mediates the Relationship between Parental Criticism and Social Anxiety. International Journal of Psychology and Psychological Therapy, 14, 33-43.

Psychogiou, L., Legge, K., Parry, E., Mann, J., Nath, S., Ford, T., \& Kuyken, W. (2016). Self-Compassion and Parenting in Mothers and Fathers with Depression. Mindfulness, 7, 896-908. https://doi.org/10.1007/s12671-016-0528-6

Raes, F., Pommier, E., Neff, K. D., \& Van Gucht, D. (2011). Construction and Factorial Validation of a Short Form of the Self-Compassion Scale. Clinical Psychology \& Psychotherapy, 18, 250-255. https://doi.org/10.1002/cpp.702

Reid, R. C., Temko, J., Moghaddam, J. F., \& Fong, T. W. (2014). Shame, Rumination, and Self-Compassion in Men Assessed for Hypersexual Disorder. Journal of Psychiatric Practice, 20, 260-268. https://doi.org/10.1097/01.pra.0000452562.98286.c5

Samaie, G., \& Farahani, H. A., (2011). Self-Compassion as a Moderator of the Relationship between Rumination, Self-Reflection and Stress. Procedia-Social and Behavioral Sciences, 30, 978-982. https://doi.org/10.1016/j.sbspro.2011.10.190

Scoglio, A. A., Rudat, D. A., Garvert, D., Jarmolowski, M., Jackson, C., \& Herman, J. L. (2015). Self-Compassion and Responses to Trauma The Role of Emotion Regulation. Journal of Interpersonal Violence, 33, 2016-2036.

https://doi.org/10.1177/0886260515622296

Trompetter, H. R., de Kleine, E., \& Bohlmeijer, E. T. (2016). Why Does Positive Mental Health Buffer Against Psychopathology? An Exploratory Study on Self-Compassion as a Resilience Mechanism and Adaptive Emotion Regulation Strategy. Cognitive Therapy and Research, 41, 459-468. https://doi.org/10.1007/s10608-016-9774-0

Waite, F., Knight, M. T., \& Lee, D. (2015). Self-Compassion and Self-Criticism in Recovery in Psychosis: An Interpretative Phenomenological Analysis Study. Journal of clinical psychology, 71, 1201-1217. https://doi.org/10.1002/jclp.22211

Werner, K. H., Jazaieri, H., Goldin, P. R., Ziv, M., Heimberg, R. G., \& Gross, J. J. (2012). Self-Compassion and Social Anxiety Disorder. Anxiety, Stress \& Coping, 25, 543-558. https://doi.org/10.1080/10615806.2011.608842

Westphal, M., Leahy, R. L., Pala, A. N., \& Wupperman, P. (2016). Self-Compassion and Emotional Invalidation Mediate the Effects of Parental Indifference on Psychopathology. Psychiatry Research, 242, 186-191. https://doi.org/10.1016/j.psychres.2016.05.040

Wetterneck, C. T., Lee, E. B., Smith, A. H., \& Hart, J. M. (2013). Courage, Self-Compassion, and Values in Obsessive-Compulsive Disorder. Journal of Contextual Behavioral Science, 2, 68-73. https://doi.org/10.1016/j.jcbs.2013.09.002

World Health Organization (1992). The ICD-10 Classification of Mental and Behavioural Disorders: Clinical Descriptions and Diagnostic Guidelines. Geneva: World Health Organization.

Xavier, A., Gouveia, J. P., \& Cunha, M. (2016). Non-Suicidal Self-Injury in Adolescence: 
The Role of Shame, Self-Criticism and Fear of Self-Compassion. In Child \& Youth Care Forum (pp. 1-16). New York: Springer. https://doi.org/10.1007/s10566-016-9346-1

Zessin, U., Dickhauser, O., \& Garbade, S. (2015). The Relationship between Self-Compassion and Well-Being: A Meta-Analysis. Applied Psychology: Health and Well-Being, 7, 340-364. https://doi.org/10.1111/aphw.12051 